\title{
Distributional Patterns of Amphibians and Reptiles in Ghandruk, Annapurna Conservation Area, Nepal
}

\author{
Bivek Gautam ${ }^{1}$, Mukesh Kumar Chalise ${ }^{1}$, Kul Bahadur Thapa ${ }^{2}$, and Santosh Bhattarai ${ }^{3}$ \\ ${ }^{1}$ Central Department of Zoology, Tribhuvan University, Kathmandu, Nepal \\ ${ }^{2}$ Himalayan Nature, POB-10918, Lazimpat, Kathmandu, Nepal \\ ${ }^{3}$ National Trust for Nature Conservation-Biodiversity Conservation Center, Ratnanagar-06, Sauraha, Chitwan-44204, Nepal (santosh.bhattarai@hotmail.com)
}

Photographs by the senior author.

\begin{abstract}
In May and October 2017, we assessed the distribution and diversity of herpetofauna in the Ghandruk region of the Annapurna Conservation Area. Using the Visual Encounter Survey (VES) protocol on 11 randomly selected transects, we recorded 662 individuals of 25 herpetofaunal species (12 amphibians and 13 reptiles). Species richness and abundance declined with increases in elevation but only the correlation between elevation and abundance was significant. Neither amphibians nor reptiles were uniformly distributed among different habitats, and species richness of both amphibians and reptiles varied significantly among habitat types. The greatest amphibian species richness was in wetlands, whereas that of reptiles was highest in forests.
\end{abstract}

P atterns of species richness, composition, and distribution for birds and mammals are known for Nepal (Hunter and Yonzan 1993; Jnawali et al. 2011) but conservation status, distributions, and population trends of the Nepalese herpetofauna are not well documented (Bhattarai et al. 2017a, 2018). This is likely due to the cryptic nature of many species, behavioral sensitivity to environments (Muñoz et al. 2016), and a lack of interest by researchers. Only the Gharial (Gavialis gangeticus) and its conservation have received substantial attention (Acharya et al. 2017; Bhattarai et al. 2018).

The first substantive study of herpetofaunal distributions in Nepal was that of Swan and Levinton (1962). Subsequently, Dubois (1974, 1984), Fleming and Fleming (1974), Kramer (1977), Nanhoe and Ouboter (1987), Zug and Mitchell (1995), Das (1998), O'Shea (1998), Shrestha (2000), Schleich and Kästle (2002), Tillack et al. (2003), Shah and Tiwari (2004), Aryal et al. (2010), Kästle et al. (2013), Khatiwada et al. (2015, 2017), Bhattarai et al. (2017b), Pandey et al. (2018), and Rawat et al. (2019) contributed new information either by describing new species or recording taxa new to the country.

Species richness, community composition, and distributions are attributed to historical and climatic factors, environmental gradients, and landscape attributes, and these can provide crucial information for prioritizing and matching conservation measures with specific sites (Hunter and
Yonzan 1993; Khatiwada and Haugaasen 2015). Recent studies suggest that herpetofaunal communities are most speciose and widely distributed at mid elevation (Naniwadekar and Vasudevan 2007; Chhetri et al. 2010; Khatiwada and Haugaasen 2015). However, few studies have addressed distribution patterns of herpetofauna in the Nepalese Himalayas and available information is largely based on checklists (e.g., Shah 2001; Schleich and Kästle 2002) and data regarding altitudinal gradients in species richness are insufficient. Consequently, we herein present information on herpetofaunal distribution patterns and influential factors (especially habitat) along altitudinal gradients in the Ghandruk unit of the Annapurna Conservation Area in western Nepal.

\section{Methods}

Study Area.-The Annapurna Conservation Area (ACA) is the largest Protected Area in Nepal with an area of 7,629 km² involving five districts of Gandaki Province. Of seven conservation units, Ghandruk, situated in the southern part of the ACA in Kaski District, covers $281.1 \mathrm{~km}^{2}$ (Dahal et al. 2014; Fig. 1). Ghandruk is a heterogeneous region comprised of forests $(22.5 \%)$, mountainous Himalayas (18.5\%), bare land and rocky areas $(5.6 \%)$, infertile land $(0.8 \%)$, residential areas (0.5\%), and agricultural lands (52.1\%) (Shrestha 2014). The topography of the area is steep, with slopes of $3-75^{\circ}$ and land features ranging from plateaus to cliffs (Giri et al. 2011). 


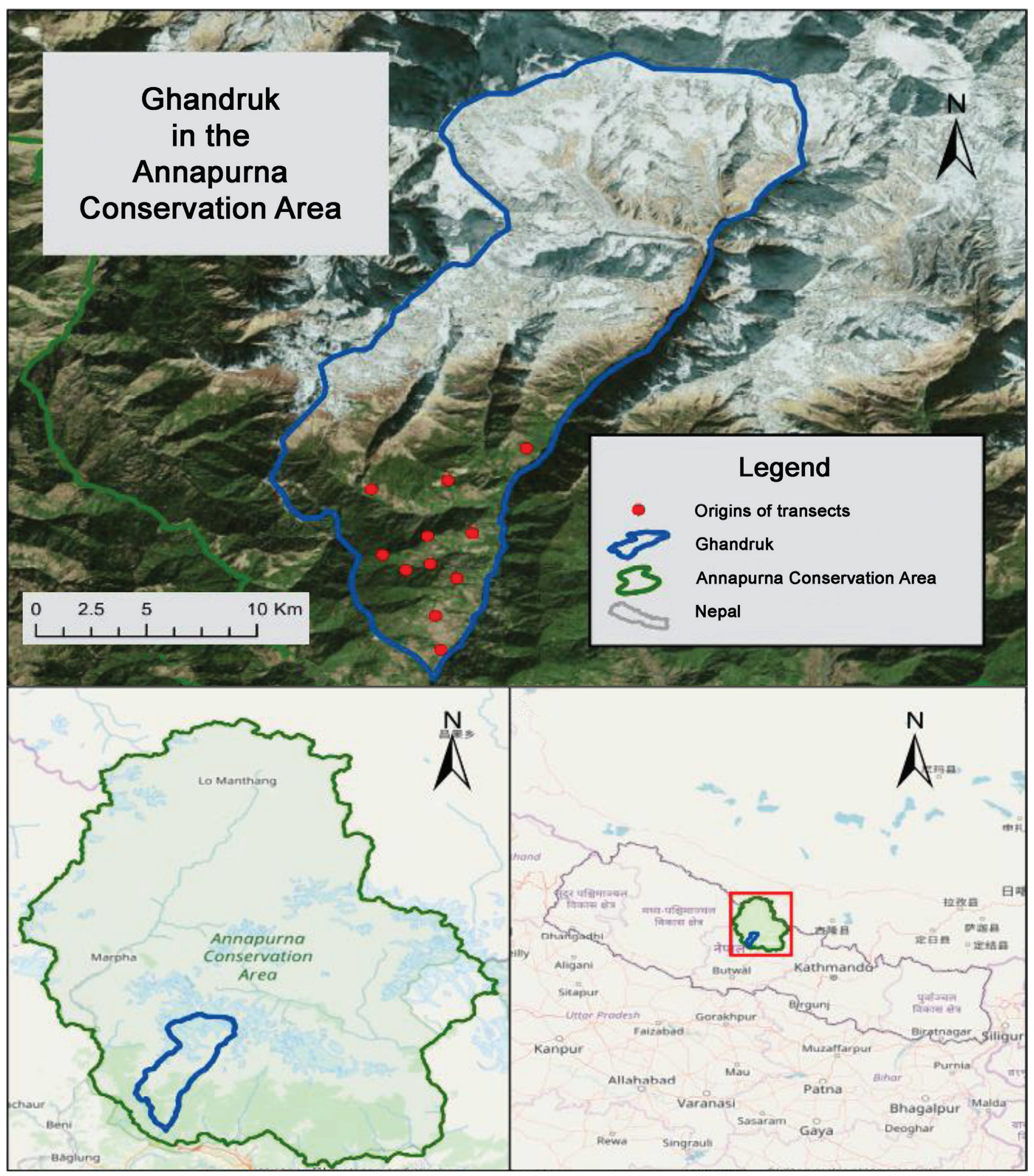

Fig. 1. Map showing the location of the Ghandruk Region of the Annapurna Conservation Area, Nepal.

The area is famous as a tourist destination for its cultural heritage and biodiversity. Included among 1,226 documented species of plants are 38 species of orchids and nine species of rhododendrons. Dominant vegetation includes Nepalese
Alder (Alnus nepalensis), Drooping Fig (Ficus semicordata), Himalayan Bird Cherry (Prunus cornuta), Tree Rhododendron (Rhododendron aroboreum), Silk Trees (Albizia spp.), Giant Cane (Arundo donax), Corydalis (Corydalis spp.), and Knotweed 
(Polygonium spp,) (Rajbhandary 2011). Vertebrate species include 128 mammals (Baral et al. 2019), 518 birds (Baral 2018), and 66 reptiles and amphibians (Kästle et al. 2013).

Field Methods.-We generated 11 random points using Arc Map 10.5 to record amphibians and reptiles. From each randomly selected point we walked $500 \mathrm{~m}$ in any possible direction and considered this as one transect. Surveys were conducted pre- and post-monsoon in May and October 2017, respectively, at elevations of 1,000 $\mathrm{m}$ and 2,700 $\mathrm{m}$ altitude. We spent 10 days searching for animals in each season, with both nocturnal (1800-2200 h) and diurnal (1000-1600 h) surveys along transects employing a Visual Encounter Survey (VES) protocol (Heyer et al. 1994). Two observers searched probable microhabitats such as under rocks, fallen logs, leaf litter and other debris, crevices, water, and vegetation to locate species along each transect. When animals were detected, we captured and measured them and took high-resolution photographs to record colors and patterns. We identified species based on morphological characters using keys in Schleich and Kästle (2002), Shah and Tiwari (2004), and Kästle et al. (2013).

Data Analysis.-For statistical tests, we used Microsoft Excel 2007 and Minitab (version 16.1.1) and we calculated herpetofaunal diversity using the Shannon-Wiener diversity index (Shannon and Wiener 1963). We considered elevation as an independent variable for both amphibians and reptiles and calculated species richness or abundance as a dependent variable. We determined species richness and abundance patterns along the elevational gradient using simple linear regression. We applied a one-way Analysis of Variance (ANOVA) to compare the distribution of herpetofauna in different habitat types, using habitat type as the independent variable and species richness and abundance as dependent variables.

\section{Results}

We recorded 25 species of herpetofauna: 535 individuals of 12 species of amphibians in four families and seven genera, and 127 individuals of 13 species of reptiles in seven families

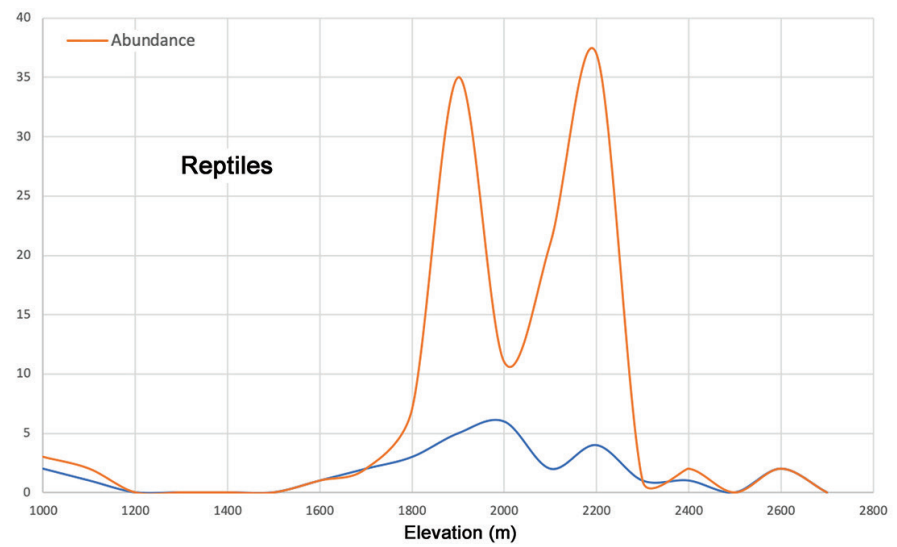

Fig. 2. Herpetofaunal species richness and abundance patterns along an elevational gradient in the Ghandruk Region of the Annapurna Conservation Area, Nepal.
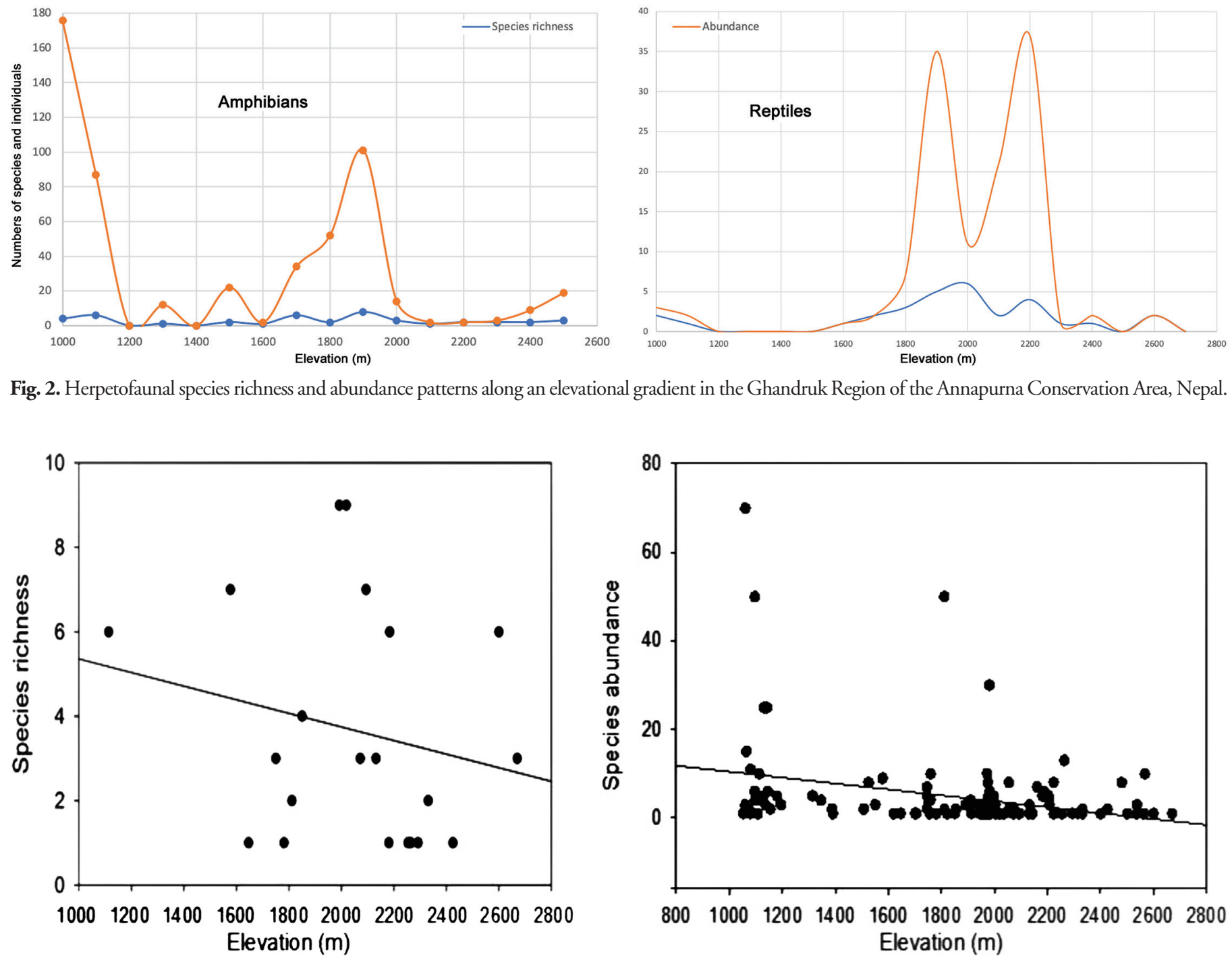

Fig. 3. The effect of elevation on herpetofaunal species richness and abundance in the Ghandruk Region of the Annapurna Conservation Area, Nepal. 


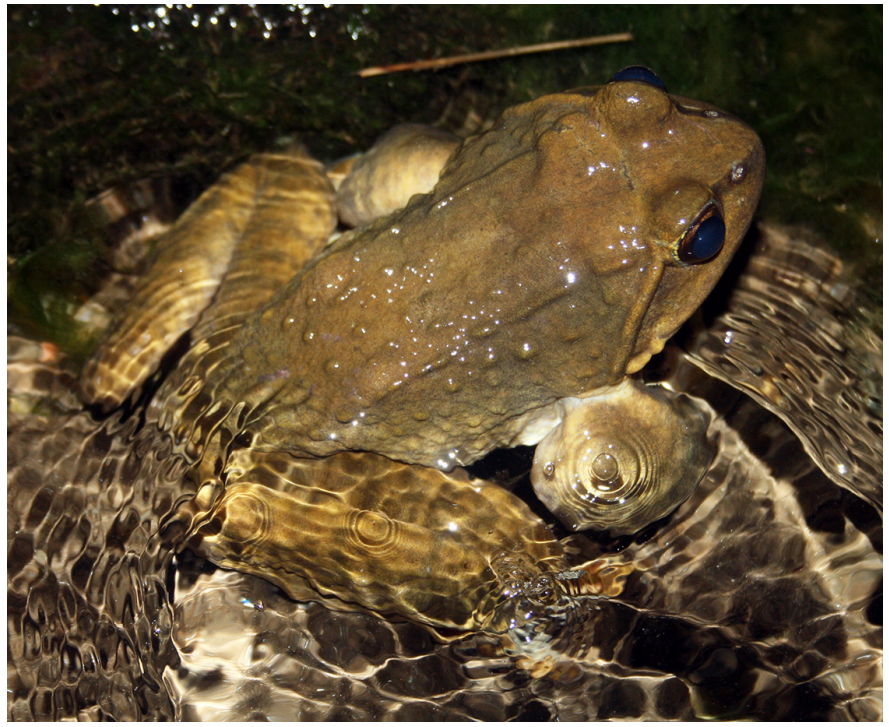

Fig. 4. A Liebig's Paa Frog (Nanorana liebigii) from the Ghandruk Region of the Annapurna Conservation Area, Nepal. and 13 genera. Four species of amphibians and one reptilian species are recorded for the first time in the region. Among amphibians, the fork-tongued frogs (Dicroglossidae) were most abundant, comprising seven of the 12 species recorded and $65.98 \%$ of the total number of individuals observed. Other amphibian families were waterfrogs (Ranidae) with two species, true toads (Bufonidae) with two species, and leaflitter frogs (Megophryidae) with one species. Among reptiles, colubrids (Colubridae) accounted for four of the 13 species recorded. Other reptilian families were agamids (Agamidae) with three species, natricids (Natricidae) with two species, and ground skinks (Sphenomorphidae), pseudoxenodontids (Pseudoxenodontidae), elapids (Elapidae), and vipers (Viperidae) with one species each.

Species richness. - Species richness of amphibians increased to an elevation of 1,900 $\mathrm{m}$ but declined above that elevation, whereas that of reptiles peaked at an elevation of about 2,000 m (Fig. 2). Elevation and species richness were

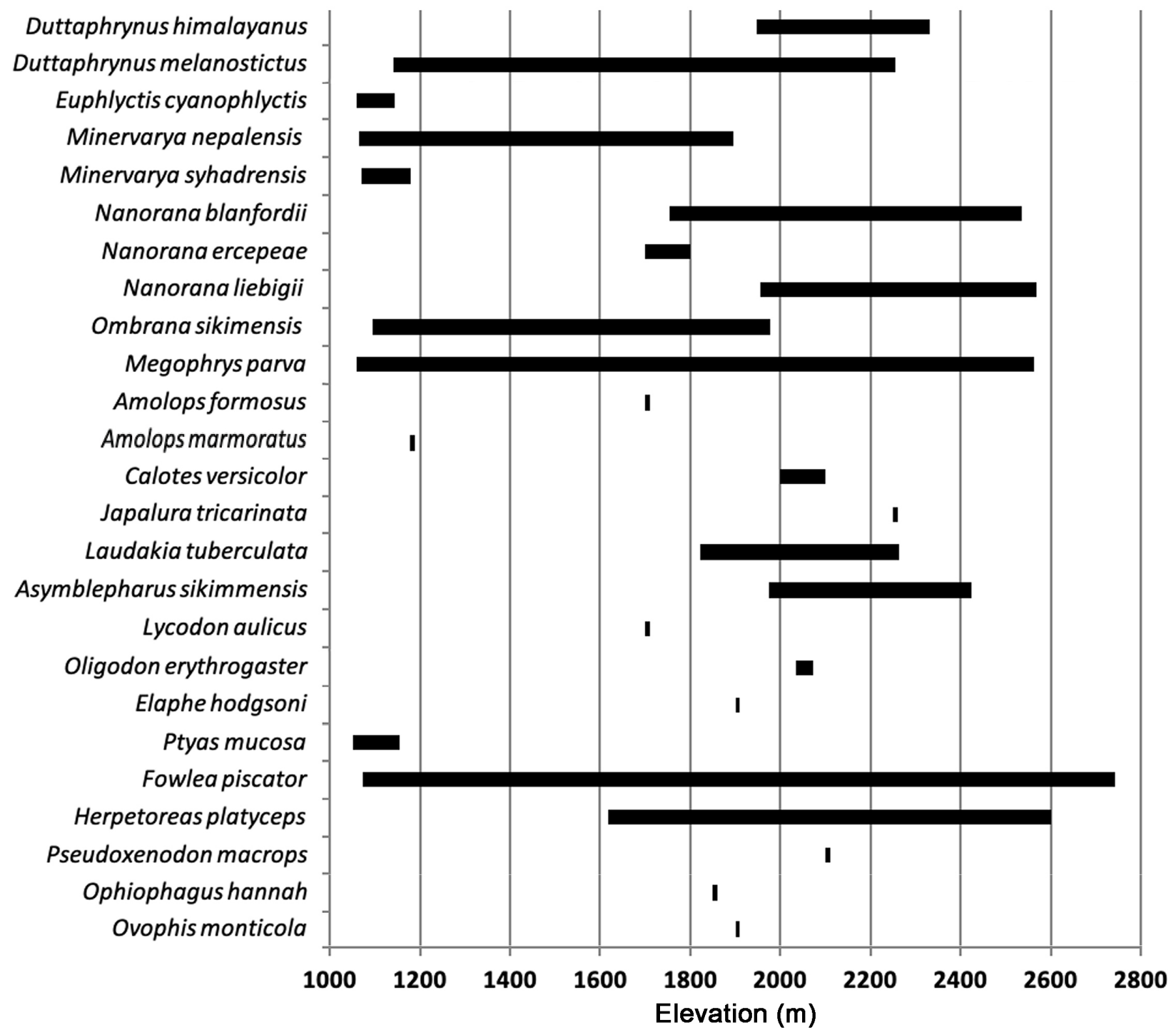

Fig. 5. Elevational ranges of herpetofaunal species in the Ghandruk Region of the Annapurna Conservation Area, Nepal. 
Table 1. Elevational ranges $(\mathrm{m})$ of herpetofauna of the Ghandruk Region of the Annapurna Conservation Area.

\begin{tabular}{|c|c|c|c|c|c|c|}
\hline Species & $\begin{array}{l}\text { Present } \\
\text { study }\end{array}$ & $\begin{array}{c}\text { Shah and } \\
\text { Tiwari (2004) }\end{array}$ & $\begin{array}{l}\text { Kästle et } \\
\text { al. (2013) }\end{array}$ & $\begin{array}{c}\text { Rai } \\
(2003)\end{array}$ & $\begin{array}{c}\text { Nanhoe and } \\
\text { Ouboter (1987) }\end{array}$ & $\begin{array}{l}\text { Thapa } \\
(2016)\end{array}$ \\
\hline \multicolumn{7}{|l|}{ Amphibians } \\
\hline Himalayan Toad & $1,947-2,331$ & $1,300-2,744$ & $1,300-2,700$ & $2,500-4,000$ & $1,300-2,650$ & - \\
\hline \multicolumn{7}{|l|}{ Duttaphrynus himalayanus } \\
\hline Common Asian Toad & $1,142-2,254$ & $<2,250$ & $<1,800$ & $56-1,000$ & $800-2,250$ & $391-1,448$ \\
\hline \multicolumn{7}{|l|}{ Duttaphrynus melanostictus } \\
\hline Nepal Cricket Frog & $1,080-1,912$ & $1,350-1,580$ & $1,350-1,580$ & $56-1,000$ & 1,500 & $462-1,387$ \\
\hline \multicolumn{7}{|c|}{ Minervarya $[=$ Fejarvarya $]$ nepalensis } \\
\hline Syadra Frog & $1,064-1,456$ & $<1,980$ & $150-1,980$ & $56-1,000$ & 1,500 & - \\
\hline \multicolumn{7}{|c|}{ Minervarya $[=$ Fejarvarya $]$ syhadrensis } \\
\hline Blanford's Paa Frog & $1,755-2,537$ & $1,800-2,920$ & $1,830-3,000$ & $2,900-4,000$ & - & - \\
\hline \multicolumn{7}{|l|}{ Nanorana ercepeae } \\
\hline \multicolumn{7}{|l|}{ Nanorana liebigii } \\
\hline Sikkimese Frog & $1,096-1,976$ & $1,210-2,500$ & $1,200-2,500$ & 3,660 & $1,210-1,770$ & - \\
\hline \multicolumn{7}{|l|}{ Ombrana sikimmensis } \\
\hline Burmese Spade-footed Toad & $1,060-2,562$ & $970-2,440$ & $970-2,480$ & $1,000-3,000$ & $1,230-2,440$ & 973 \\
\hline \multicolumn{7}{|l|}{ Megophrys [= Xenophrys] parva } \\
\hline Assam Cascade Frog & 1,700 & $1,190-2,896$ & - & $1,000-3,000$ & $1,800-2,650$ & - \\
\hline \multicolumn{7}{|l|}{ Amolops formosus } \\
\hline Marbled Cascade Frog & 1,100 & $840-2,896$ & $1,000-1,900$ & - & $1,040-1,840$ & - \\
\hline \multicolumn{7}{|l|}{ Amolops marmoratus } \\
\hline \multicolumn{7}{|l|}{ Reptiles } \\
\hline \multicolumn{7}{|l|}{ Laudakia tuberculata } \\
\hline \multicolumn{7}{|l|}{ Asymblepharus sikimmensis } \\
\hline Common Wolfsnake & 1,700 & $100-2,130$ & $150-2,100$ & $1,000-3,000$ & $914-2,130$ & $389-706$ \\
\hline \multicolumn{7}{|l|}{ Lycodon aulicus } \\
\hline Red-bellied Kukri Snake & $2,035-2,072$ & $1,525-2,600$ & $1,525-2,000$ & - & - & $1,500-2,000$ \\
\hline \multicolumn{7}{|l|}{ Oligodon erythrogaster } \\
\hline Hodgson's Ratsnake & 1,900 & $1,000-3,200$ & $1,000-3,000$ & $1,000-3,000$ & $2,740-3,200$ & $1,172-1,272$ \\
\hline Orthriophis $[=$ Elaphe $]$ hodgson & & & & & & \\
\hline Oriental Ratsnake & $1,052-1,155$ & $100-1,750$ & $<3,000$ & - & $800-1,750$ & $385-1,387$ \\
\hline Ptyas mucosa & & & & & & \\
\hline Checkered Keelback* & $1,073-2,670$ & $100-700$ & $<700$ & $56-1,000$ & $960-1,500$ & $392-1,387$ \\
\hline Fowlea $[=$ Xenochrophis $]$ piscate & & & & & & \\
\hline Himalayan Keelback & $1,619-2,600$ & $1,040-3,657$ & $1,500-3,600$ & $1,000-3,000$ & $1,040-3,100$ & $900-1,265$ \\
\hline Herpetoreas platyceps & & & & & & \\
\hline Large-eyed Bamboo Snake & 2,200 & $1,200-2,360$ & $<1,800$ & - & $2,000-2,360$ & - \\
\hline Pseudoxenodon macrops & & & & & & \\
\hline King Cobra & 1,800 & $100-3,500$ & $150-1,530$ & - & - & $593-663$ \\
\hline Ophiophagus hannah & & & & & & \\
\hline Oriental Mountain Pitviper & 1,900 & $1,320-2,680$ & $1,320-2,250$ & $1,000-3,000$ & $1,550-1,900$ & 1,800 \\
\hline
\end{tabular}




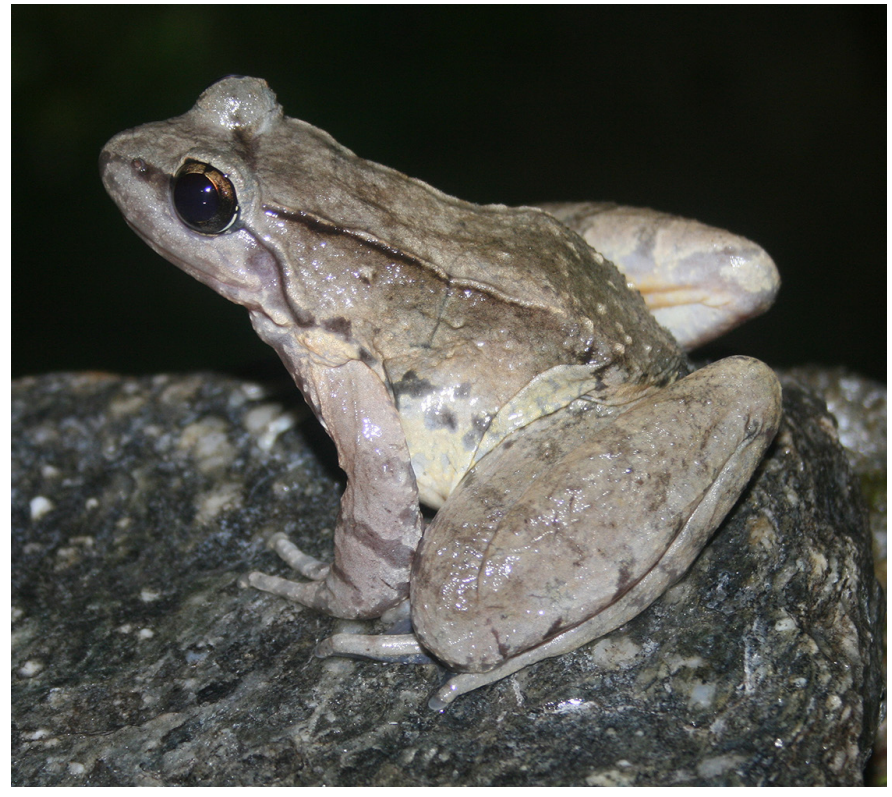

Fig. 6. A Sikkimese Frog (Ombrana sikimensis) from the Ghandruk Region of the Annapurna Conservation Area, Nepal.

negatively correlated, but the linear relationship was not significant $\left(\mathrm{r}^{2}=0.009018, \mathrm{p}=0.9256\right)$; however, we did find a significant linear pattern between species abundance and elevation $\left(r^{2}=0.09321, \mathrm{p}<0.05\right)$ (Fig. 3).

The abundance of herpetofauna was irregularly distributed along the elevational gradient (Fig. 2). The maximum abundance of amphibians was at $1,000 \mathrm{~m}$, dropped to zero at $1,200 \mathrm{~m}$ and $1,400 \mathrm{~m}$, and showed a secondary peak at an elevation of $1,900 \mathrm{~m}$. Reptilian abundance showed dual peaks at about $1,900 \mathrm{~m}$ and 2,200 m. Among amphibian species, Liebig's Paa Frog (Nanorana liebigii; Fig. 4) was found at the highest elevation $(2,567 \mathrm{~m})$ and the Skittering Frog (Euphlyctis cyanophlyctis) was found at the lowest elevation

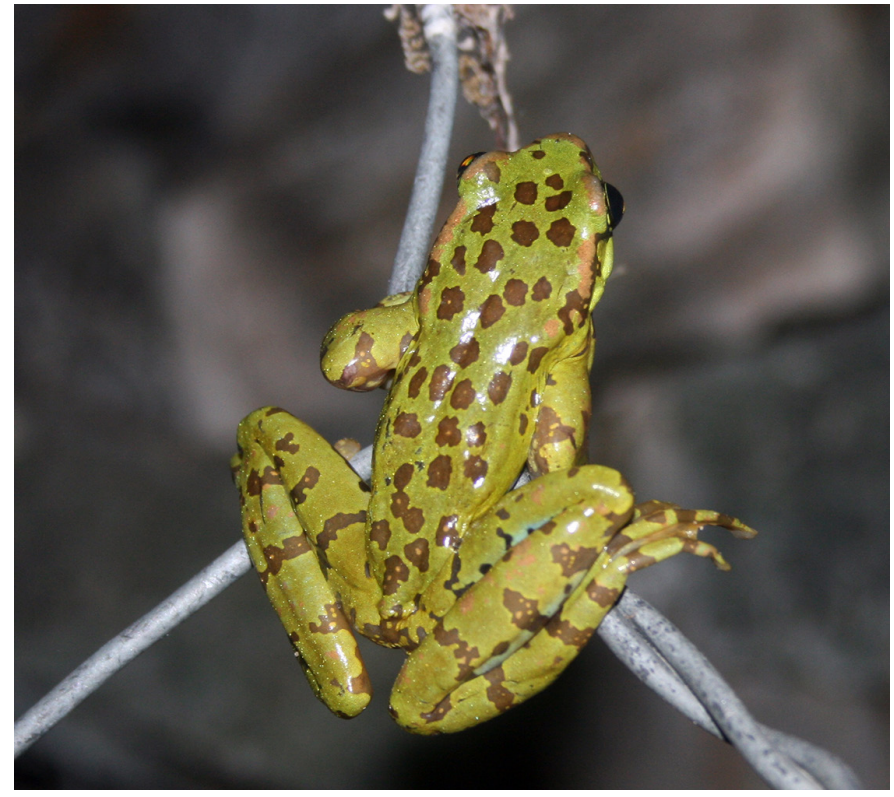

Fig. 8. An Assam Cascade Frog (Amolops formosus) from the Ghandruk Region of the Annapurna Conservation Area, Nepal.

$(1,058 \mathrm{~m})$. Among reptilian species, the Oriental Ratsnake (Ptyas mucosa) was recorded at the lowest elevation $(1,052$ $\mathrm{m})$ and the Checkered Keelback (Fowlea [= Xenochrophis] piscator) was recorded at the highest elevation $(2,670 \mathrm{~m})$. Many species were distributed over a wide elevational range (Fig. 5), with the Burmese Spade-footed Toad (Megophrys [= Xenophrys] parva) and the Checkered Keelback having the greatest elevational ranges among amphibians and reptiles, respectively. We recorded five species beyond their previously known elevational range (Table 1). We found Blanford's Paa Frog (Nanorana blanfordii), R.C.P.'s Paa Frog (N. ercepeae), and the Sikkimese Frog (Ombrana sikimensis; Fig. 6) at elevations below those previously reported. The Nepal Cricket

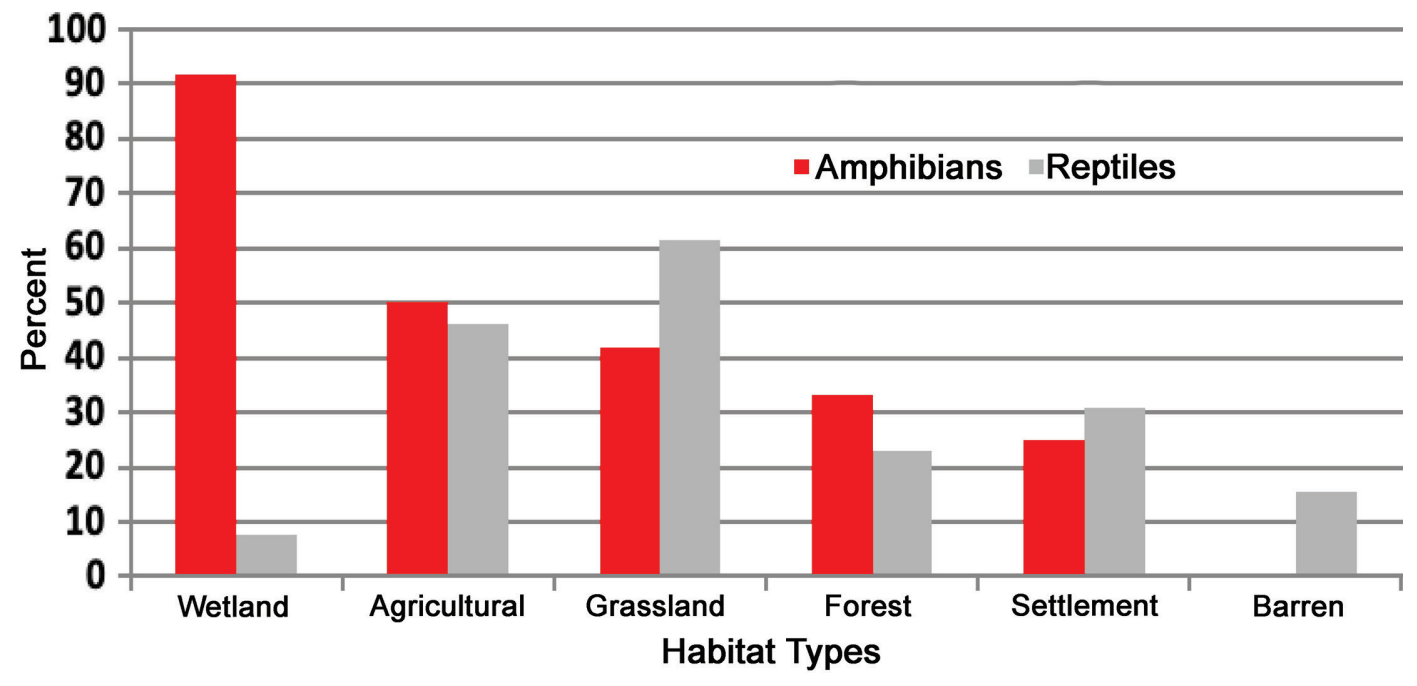

Fig. 7. Species richness of amphibians and reptiles in different habitat types in the Ghandruk Region of the Annapurna Conservation Area, Nepal. 


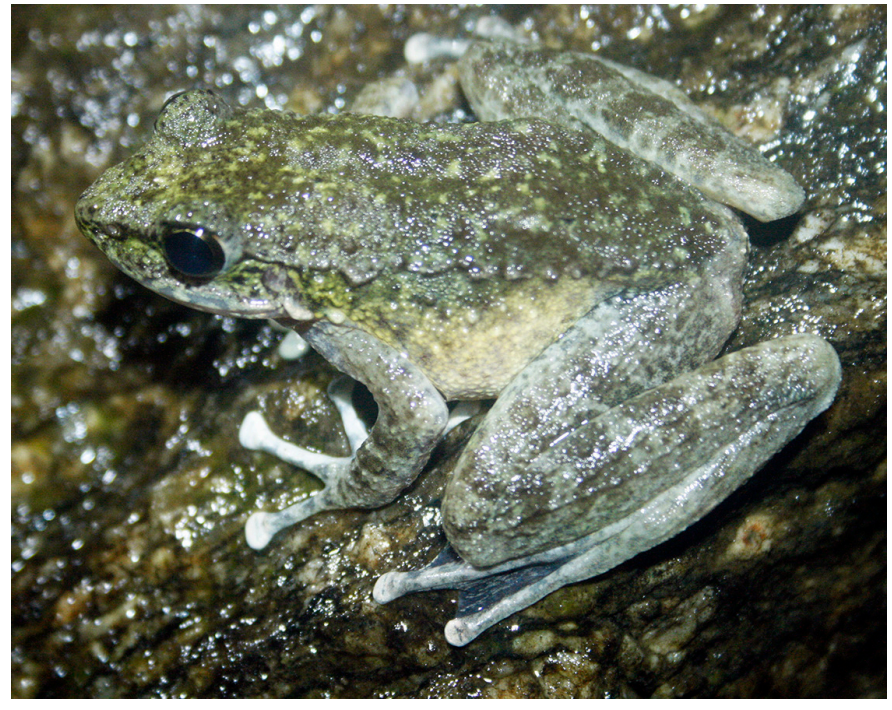

Fig. 9. A Marbled Cascade Frog (Amolops marmoratus) from the Ghandruk Region of the Annapurna Conservation Area, Nepal.

Frog (Minervarya $[=$ Fejarvarya $]$ nepalensis) and Fowlea piscator were recorded at elevations higher than their previously known elevational ranges.

Species distribution among habitat types.-The results of one-way ANOVAs showed that both amphibians and reptiles are not uniformly distributed among habitat types (Fig. 7), with both amphibian $(\mathrm{F}=6.26, \mathrm{P}<0.001)$ and reptilian $(\mathrm{F}=$ $2.69, \mathrm{p}<0.05)$ species richness differing significantly among habitat types. The maximum number of amphibian species were in wetlands (11 of 12 species) followed by grasslands ( 6 species), forest (5), agricultural areas (4), and settlements (3). None were in barren habitat. R.C.P.'s Paa Frog (Nanorana ercepeae), the Sikkimese Frog (Ombrana sikimensis), and the Assam Cascade Frog (Amolops formosus; Fig. 8) were recorded

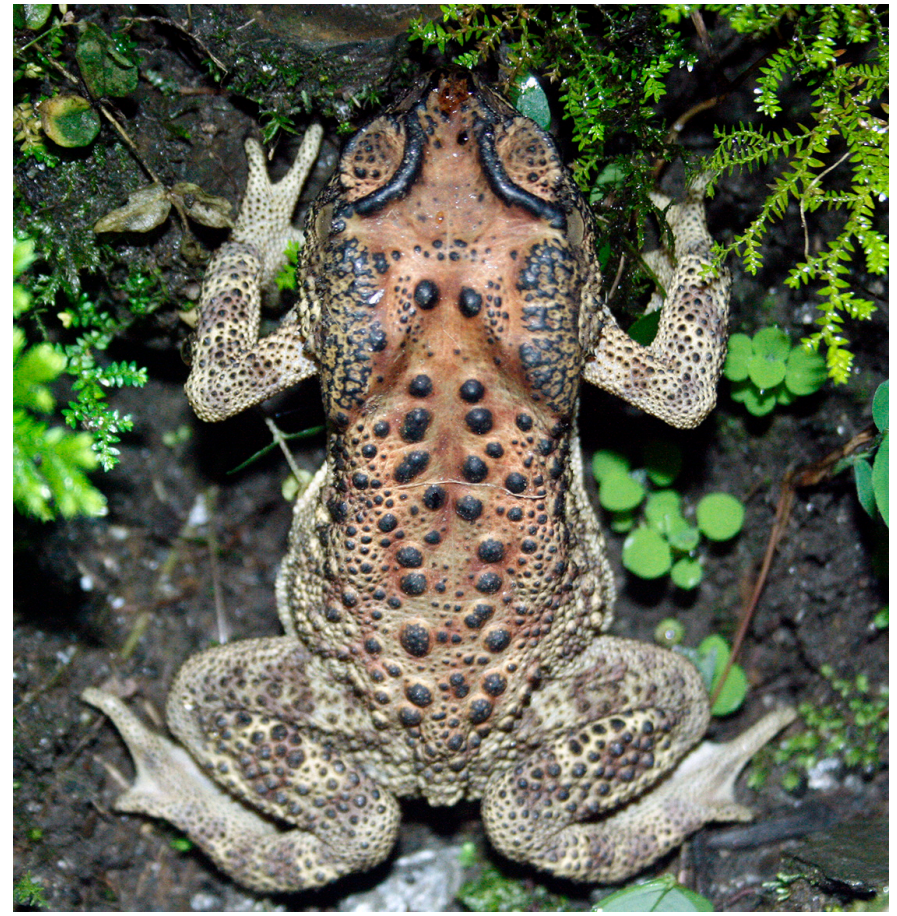

Fig. 10. A Common Asian Toad (Duttaphrynus melanostictus) from the Ghandruk Region of the Annapurna Conservation Area, Nepal.

from single habitat types and Liebig's Paa Frog (Nanorana liebigii) and the Syadra Frog (Minervarya [= Fejarvarya] syhadrensis) were recorded from two habitat types. The Nepal Cricket Frog (Minervarya [= Fejarvarya] nepalensis), Blanford's Paa Frog (Nanorana blanfordii), and the Marbled Cascade Frog (Amolops marmoratus; Fig. 9) were recorded from three habitat types; the Himalayan Toad (Duttaphrynus himalayanus) and the Common Asian Toad (Duttaphrynus melanostictus; Fig. 10) from four habitat types; and the

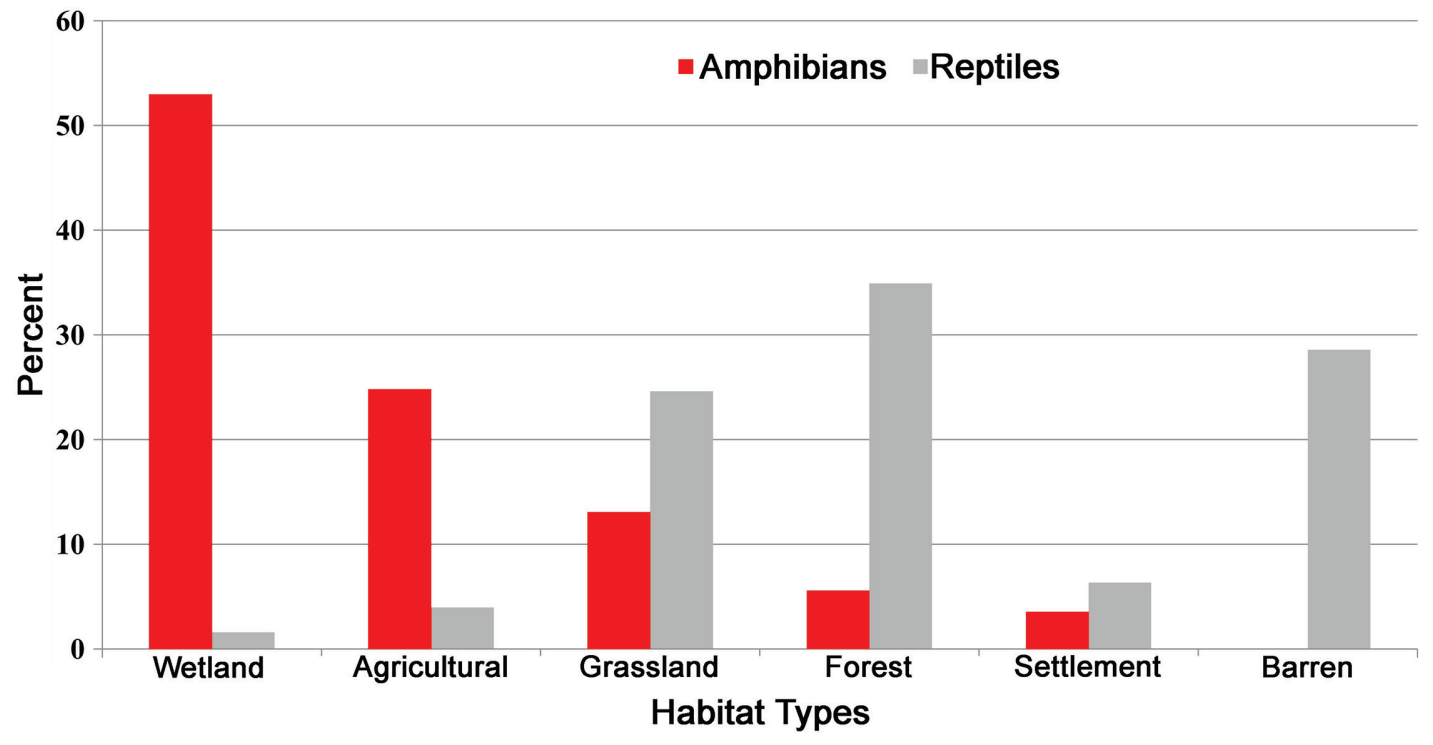

Fig. 11. Abundance of amphibians and reptiles in different habitat types in the Ghandruk Region of the Annapurna Conservation Area, Nepal. 
Table 2. Records of herpetofauna in the Ghandruk Region of the Annapurna Conservation Area. Habitats: $A=$ Agricultural land, $B=B a r r e n$ land, $\mathrm{F}=$ Forest, $\mathrm{G}=$ Grassland, $\mathrm{S}=$ Settlement, $\mathrm{W}=$ Wetland.

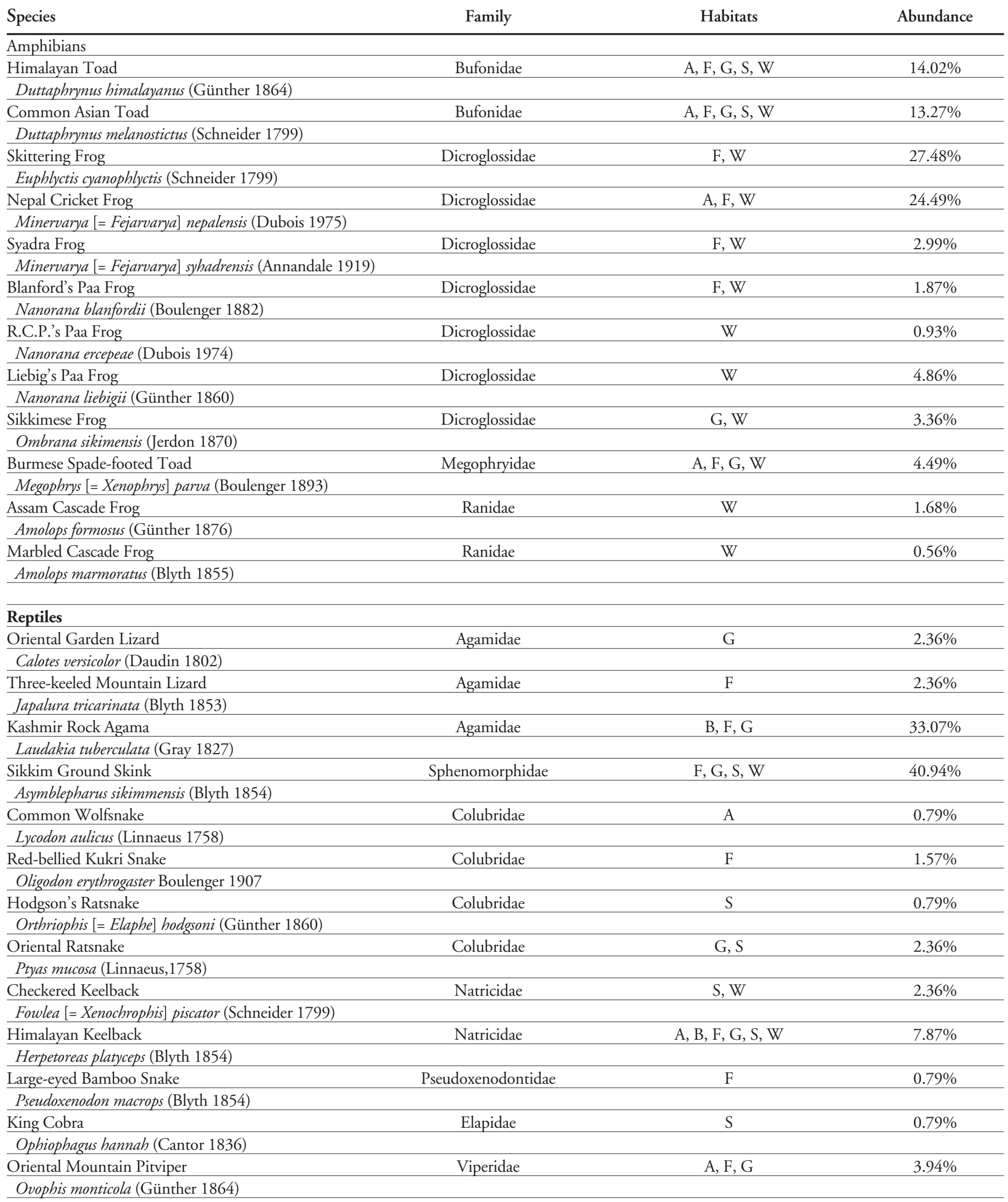




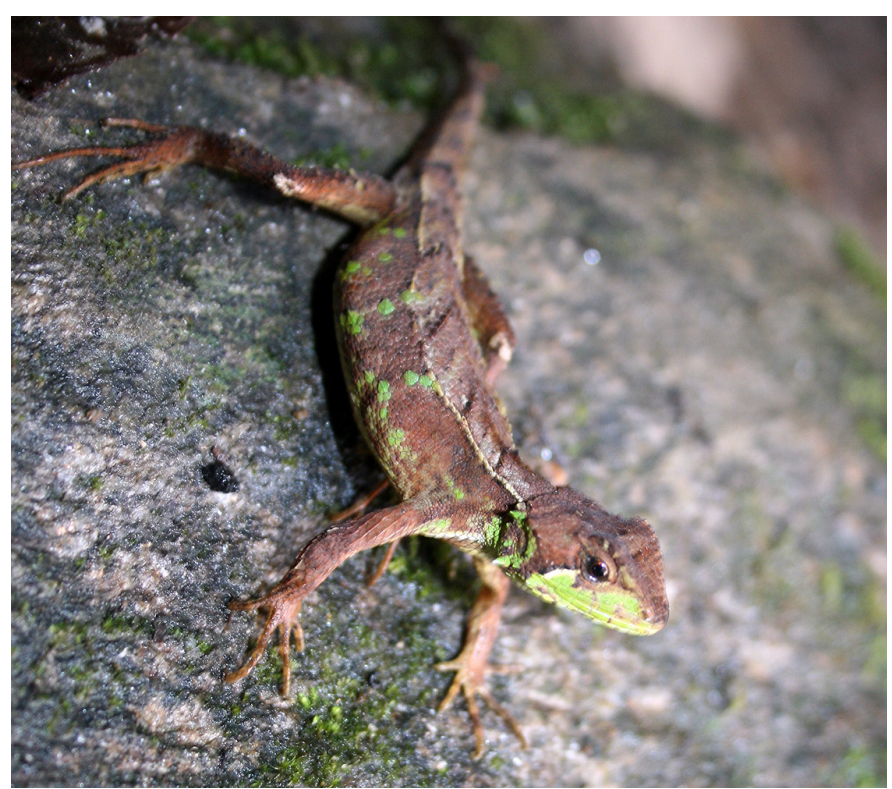

Fig. 12. A Three-keeled Mountain Lizard (Japalura tricarinata) from the Ghandruk Region of the Annapurna Conservation Area, Nepal.

Burmese Spade-footed Toad (Megophrys [= Xenophrys $]$ parva) from five habitat types. The maximum number of reptilian species were in forested habitats ( 8 of 13 species), followed by grasslands (6), settlements (4), agricultural lands (3), barren habitats (2), and wetlands (1).

Species abundance among habitat types.-Although the abundance of reptiles and amphibians varied in different habitat types, only the abundance of amphibians differed significantly (Table 2). The greatest number of reptiles was found in the forest ( 44 of 127 individuals), followed by barren land (36), grasslands (31), settlements (8), agricultural land (5), and wetlands (1) (Fig. 11). Among reptiles, the Common Wolfsnake (Lycodon aulicus), Oriental Ratsnake (Ptyas mucosa), Red-bellied
Kukri Snake (Oligodon erythrogaster), King Cobra (Ophiophagus hannah), Large-eyed Bamboo Snake (Pseudoxenodon macrops), Hodgson's Ratsnake (Orthriophis [= Elaphe] hodgsoni), Oriental Garden Lizard (Calotes versicolor), and Three-keeled Mountain Lizard (Japalura tricarinata; Fig. 12) were recorded from a single habitat type; the Checkered Keelback (Fowlea [= Xenochrophis] piscator) and Oriental Mountain Pitviper (Ovophis monticola; Fig. 13) were recorded from two habitat types; the Kashmir Rock Agama (Laudakia tuberculata) and Sikkim Ground Skink (Asymblepharus sikimmensis) from three habitat types; and the Himalayan Keelback (Herpetoreas platyceps) was found in all six habitat types surveyed.

\section{Discussion}

Previous studies by Nanhoe and Ouboter (1987), Shah (2001), Shah and Tiwari (2004), Giri (2013), and Kästle et al. (2013) recorded a total of 66 species of amphibians and reptiles from the entire Annapurna Conservation Area. In this study, we recorded 25 species from the Ghandruk Region of the ACA. Amphibians were more abundant and had a higher diversity index than reptiles. Skittering Frogs and Kashmir Rock Agamas were the most abundant amphibians and reptiles, respectively. R.C.P.'s Paa Frog (Nanorana ercepeae) is an endemic Nepalese species described by Dubois (1974) from Bajhang, Nepal. We recorded this species for the first time from Annapurna Conservation Area, ca. 300 km (aerial distance) east of its type locality. Khambu (2011) recorded this species from Ilam District, ca. $420 \mathrm{~km}$ east of our location. These records suggest that $N$. ercepeae has a wider distribution in Nepal than previously believed.

Naniwadekar and Vasudevan (2007) noted an increase in anuran species richness in the southern Western Ghats of India, with a peak at 1,200 $\mathrm{m}$ (the highest elevation they sampled), and Chettri et al. (2010) found a consistent decline

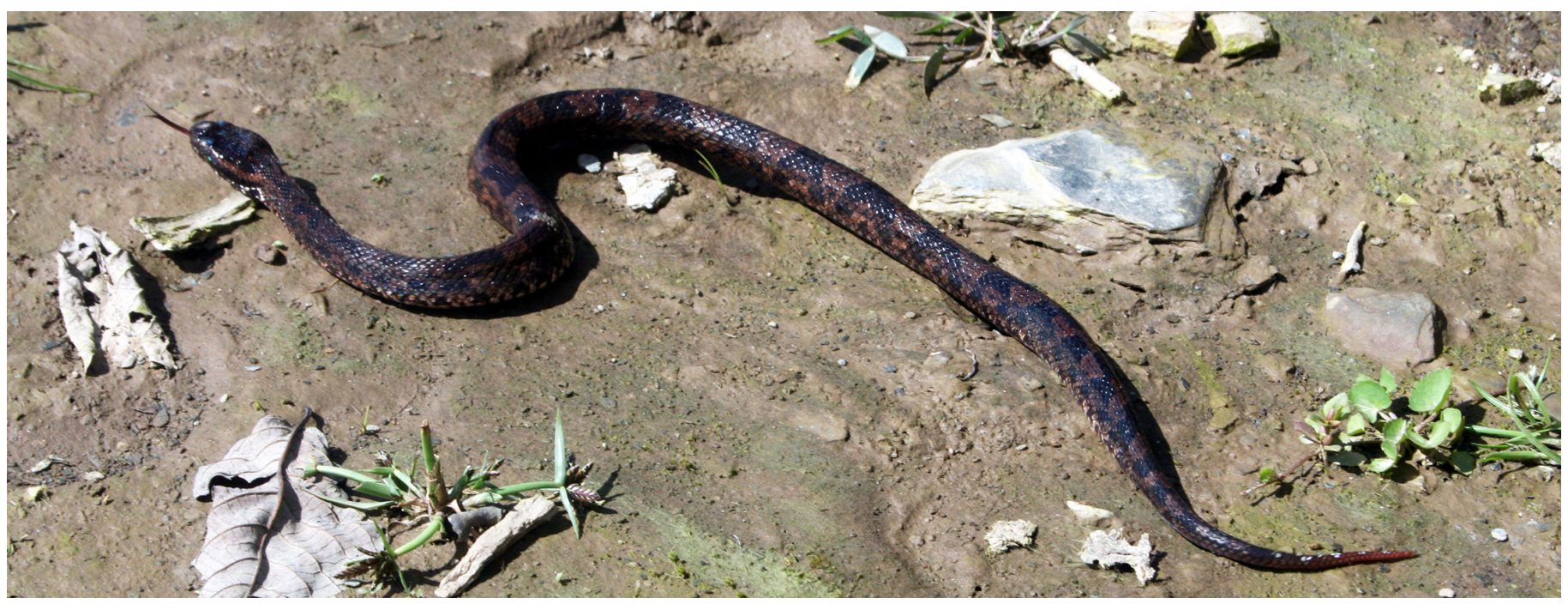

Fig. 13. An Oriental Mountain Pitviper (Ovophis monticola) from the Ghandruk Region of the Annapurna Conservation Area, Nepal. 
in reptilian species richness along an elevational gradient of $300-4,800 \mathrm{~m}$ in Sikkim Himalaya. That species richness in the Ghandruk Region peaked at 1,900-2,000 m suggests that the trend noted by Naniwadekar and Vasudevan (2007) for amphibians might only be relevant at lower elevations than those sampled in our study. The peak we recorded for reptiles might reflect peculiar features of habitat or the reptilian community in the Ghandruk Region.

The peaks in amphibian abundance at $1,000 \mathrm{~m}$ and 1,900 m probably reflect the abundance of Skittering Frogs (Euphlyctis cyanophlyctis), the most abundant species encountered and all at the lowest elevations we sampled, and the corresponding peak in species richness, respectively. The dual peaks in reptilian abundance at about $1,900 \mathrm{~m}$ and 2,200 $\mathrm{m}$ almost certainly reflect the abundance of Kashmir Rock Agamas (Laudakia tuberculata), the most frequently encountered reptiles, which have a relatively narrow elevational range that corresponds to the peaks in abundance.

Many of the species in the Ghandruk Region (and most of those for which sample sizes were relatively large) exhibited a wide elevational range. Although some reptiles and amphibians are specialized for a particular microhabitat, have narrow tolerance to climatic variations, and might be confined to narrow elevational zones (Chettri et al. 2010), many taxa inhabiting higher elevations have comparatively large climatic tolerances (Stevens 1992; Hu et al. 2011) and thus have greater elevational ranges.

\section{Acknowledgements}

We are grateful to the National Trust for Nature ConservationAnnapurna Conservation Area Project (NTNC-ACAP) and the Department of National Parks and Wildlife Conservation for permission to carry out this study in Ghandruk. This work was financially supported by the Annapurna Conservation Area Project (ACAP) and IDEA WILD supported research equipment. We thank Dipendra Simkhada and Keshav Chokhal for assistance in the field, Karan Bahadur Shah and Hermann Schleich for species identification, Daya Ram Bhusal and Janak Raj Khatiwada for assistance with data analysis, and Rajesh Sigdel for map preparation.

\section{Literature Cited}

Acharya, K.P., B.K. Khadka, S.R. Jnawali, S. Malla, S. Bhattarai, E. Wikramanayake, and M. Kohl. 2017. Conservation and population recovery of Gharials (Gavialis gangeticus) in Nepal. Herpetologica 73: 129-135.

Aryal, P.C., M.K. Dhamala, B.B. Bhurtel, M.K. Suwal, and B. Rijal. 2010. Turtles of Nepal: A Field Guide for Species Accounts and Distribution. Environmental Graduates in Himalaya, Resources Himalaya Foundation, and Companions for Amphibians and Reptiles, Kathmandu, Nepal.

Baral, R. 2018. Birds of Annapurna Conservation Area. Annapurna Conservation Area Project, National Trust for Nature Conservation, Pokhara, Nepal.

Baral, R., A. Subedi, and S.K. Yadav. 2019. Wild mammals of the Annapurna Conservation Area. Annapurna Conservation Area Project, National Trust for Nature Conservation, Pokhara, Nepal.

Bhattarai, S., C.P. Pokheral, B.R. Lamichhane, and N. Subedi. 2017a. Herpetofauna of a Ramsar Site: Beeshazar and Associated Lakes, Chitwan
National Park Nepal. Reptiles \& Amphibians 24: 17-29.

Bhattarai, S., L. Chalise, A. Gurung, C.P. Pokheral, N. Subedi, and V. Sharma. 2017b. Geographic distribution: Liopeltis calamaria (Lined Stripe-necked snake). Herpetological Review 48: 129.

Bhattarai, S., C.P. Pokheral, B.R. Lamichhane, U.R. Regmi, A.K. Ram, and N. Subedi. 2018. Amphibians and reptiles of Parsa National Park, Nepal. Amphibian \& Reptile Conservation 12: 35-48.

Chettri, B., S. Bhupathy, and B.K. Acharya. 2010. Distribution pattern of reptiles along an eastern Himalayan elevation gradient, India. Acta Oecologica 36: $16-22$.

Dahal, S., S.K. Nepal, and M.A. Schuett. 2014. Examining marginalized communities and local conservation institutions: The case of Nepal's Annapurna Conservation Area. Environmental Management 55: 219-230.

Das, I.1998. A new species of Rana from the Terai of Nepal. Journal of Herpetology 32: $223-229$

Dubois, A. 1974. Liste commmentée d'Amphibiens récoltés au Nepal. Bulletin du Muséum National d'Histoire Naturelle (3) 213 (Zoologie 143): 341-411.

Dubois, A. 1984. Note preliminaire sur le groupe de Rana limnocharis Gravenhorst, 1829 (Amphibiens, Anoures). Alytes 3: 143-159.

Dubois, A. 1987. Miscellanea taxinomica batrachologica (I). Alytes 5: 7-95.

Fleming, R.L., Jr. and R.L. Fleming, Sr. 1973. Some snakes from Nepal. Journal of the Bombay Natural History Society 3: 426-437.

Giri, B. 2013. Diversity and Distribution of Amphibians in Annapurna Conservation Area, Nepal. The Rufford Small Grants Foundation, London, UK.

Giri, S, A. Aryal, R.K. Koirala, B. Adhikari, and D. Raubenheimer. 2011. Feeding ecology and distribution of Himalayan serow (Capricornis thar) in Annapurna Conservation Area, Nepal. World Journal of Zoology 6: 80-85.

Heyer, W.R., M.A. Donnelly, R.W. Mcdiarmid, L.C. Hayek, and M.S. Foster.1994. Measuring and Monitoring Biological Diversity: Standard Methods for Amphibians. Smithsonian Institution Press, Washington, DC.

Hu, J., F. Xie, C. Li, and J. Jiang. 2011. Elevational patterns of species richness, range and body size for Spiny Frogs. PLoS ONE 6: e19817.

Hunter, M.L., Jr. and P. Yonzon.1993. Altitudinal distributions of birds, mammals, people, forests, and parks in Nepal. Conservation Biology 7: 420-423.

Khatiwada, J.R. and T. Haugaasen. 2015. Anuran species richness and abundance along an elevational gradient in Chitwan, Nepal. Zoology and Ecology 25: 110-119.

Jnawali, S.R., H.S. Baral, S. Lee, K.P. Acharya, G.P. Upadhyay, M. Pandey, R. Shrestha, D. Joshi, B.R. Laminchhane, J. Griffiths, A.P. Khatiwada, N. Subedi, and R. Amin. 2011. The Status of Nepal Mammals. The National Red List Series, Department of National Parks and Wildlife Conservation, Kathmandu, Nepal.

Kästle, W., K. Rai, and H.H. Schleich. 2013. Field Guide to Amphibians and Reptiles of Nepal. ARCO-Nepal e.V., München, Germany.

Khambu, K.R.R. 2011. Amphibians of Kangchenjunga-Singalilla complex, Nepal. Environmental Conservation Society, Jhapa, Nepal.

Khatiwada, J.R., B. Wang, S. Ghimire, K. Vasudevan, S. Paudel, and J. Jiang. 2015. A new species of the genus Tylototriton (Amphibia: Urodela: Salamandridae) from Eastern Himalaya. Asian Herpetological Research 6: 245-256.

Khatiwada, J.R., G.C. Shu, S.H. Wang, A. Thapa, B. Wang, and J. Jiang. 2017. A new species of the genus Microhyla (Anura: Microhylidae) from Eastern Nepal. Zootaxa 4252: 221-239.

Kramer, U. 1977. Zur Schlangenfauna Nepals. Revue Suisse de Zoologie 84: 721-761.

Muñoz, A., X. Santos, and Á.M. Felicísimo. 2016. Local-scale models reveal ecological niche variability in amphibian and reptile communities from two contrasting biogeographic regions. PeerJ 4: e2405.

Nanhoe, L.M.R. and P.E. Ouboter. 1987. The distribution of reptiles and amphibians in the Annapurna-Dhaulagiri Region (Nepal). Zoologische Verhandelingen 240: 1-105.

Naniwadekar, R. and K. Vasudevan. 2007. Patterns in diversity of anurans along an elevational gradient in the Western Ghats, South India. Journal of Biogeography 34: 842-853.

O'Shea, M. 1998. Herpetological results of two short field excursions to the Royal Bardia region of western Nepal, including range extensions for Assamese/IndoChinese snake taxa, pp. 306-317. In: A. de Silva (ed.), Biology and Conservation of the Amphibians, Reptiles, and Their Habitats in South Asia. Amphibian and Reptile Research Organization of Sri Lanka (ARROS), Peradenia, Sri Lanka. 
Pandey, D.P., D. Jelic, S. Sapkota, H.M. Lama, B. Lama, K. Pokharel, M. Goode, and U. Kuch. 2018. New records of snakes from Chitwan National Park and vicinity, Central Nepal. Herpetology Notes 11: 679-696.

Rai, K.R. 2003. Environmental Impacts, Systematics and Distribution of Herpetofauna from East Nepal. Unpublished Ph.D. Thesis. Central Department of Zoology, Tribhuvan University, Kathmandu, Nepal.

Rajbhandary, S. 2011. Botanical expedition to Macchapuchare Base Camp in central Nepal. Newsletter of Himalayan Botany 11(1): 1-6.

Rawat, Y.B., K.B. Thapa, S. Bhattarai, and K.B. Shah. 2019. First records of the Common Leopard Gecko, Eublepharis macularius (Blyth 1854) (Eublepharidae), in Nepal. Reptiles \& Amphibians 26: 58-61.

Schleich, S.H. and W. Kästle (eds.). 2002. Amphibians and Reptiles of Nepal: Biology, Systematics, Field Guide. A.R.G. Gantner Verlag KG, Ruggell, Liechtenstein.

Shah, K.B. and S. Tiwari. 2004. Herpetofauna of Nepal: A Conservation Companion. IUCN Nepal, Kathmandu, Nepal.

Shah, K.B. 2001. Herpetofauna and ethnoherpetology of the southern Annapurna Region, Kaski District, Nepal. Journal of Natural History Museum, Tribhuvan University 20: 105-128.

Shannon, C.E. and W. Weiner. 1963. The Mathematical Theory of Communication. University of Illinois Press, Urbana, Illinois.
Shrestha, P. 2014. Visitor experiences in Ghandruk village, Nepal. Unpublished M.Sc. Thesis, School of Tourism and Hospitality Management, Lapland University, Rovaniemi, Finland.

Shrestha, T.K. 2000. Herpetology of Nepal: A Field Guide to Amphibians and Reptiles of Trans-Himalayan Region of Asia. Steven Simpson Natural History Books, Norwich, UK.

Stevens, G. 1992. The elevational gradient in altitudinal range: An extension of Rapoport's latitudinal rule to altitude. American Naturalist 140: 893-911.

Swan, L.W. and A.E. Levinton.1962. The herpetology of Nepal: A history, checklist and zoogeographical analysis of the herpetofauna. Proceedings of the California Academy of Sciences 32: 103-147.

Thapa, K.B. 2016. Herpetofaunal diversity of Palpa District, Nepal. Unpublished M.Sc. Thesis, Central Department of Zoology, Tribhuvan University, Kathmandu, Nepal.

Tillack, F., M. Lorenz, N.L. Orlov, N. Helfenberger, K.B. Shah, and W. Eckert. 2003. Shah's Grubenotter Trimeresurus karanshahi Orlov \& Helfenberger, 1997 - ein Juniorsynonym von Trimeresurus tibetanus Huang, 1982 (Serpentes: Viperidae: Crotalinae), mit Angaben zur Verbreitung, Biologie und der Vorstellung neuer Farbvarianten aus Zentral-Nepal. Sauria 25(2): 3-15.

Zug, G.R. and J.C. Mitchell.1995. Amphibians and reptiles of the Royal Chitwan National Park, Nepal. Asiatic Herpetological Research 6: 172-180. 